Article

\title{
Suitable Re-Use of Abandoned Quarries for Restoration and Conservation of the Old City of Salamanca-World Heritage Site
}

\author{
Luís Sousa $^{1,2, *(\mathbb{D} \text {, José Lourenço }}{ }^{1,2(\mathbb{D})}$ and Dolores Pereira ${ }^{3}(\mathbb{D}$ \\ 1 Department of Geology, University of Trás-os-Montes e Alto Douro, Quinta de Prados, \\ 5000-801 Vila Real, Portugal \\ 2 CGeo Research Centre, University of Coimbra-Pólo II, 3030-790 Coimbra, Portugal \\ 3 Departamento de Geología, University of Salamanca, 37008 Salamanca, Spain \\ * Correspondence: 1sousa@utad.pt
}

Received: 28 June 2019; Accepted: 7 August 2019; Published: 12 August 2019

check for updates

\begin{abstract}
Martinamor granite has been used for centuries in the monumental buildings of Salamanca city. In this study, the fracturing pattern of the Martinamor granite outcrops was evaluated in order to assess the possibility of supplying material for the restoration of heritage monuments. Several joint sets with a mean joint spacing lower than one meter compose the fracturing pattern, making the massive exploitation of this granite impossible. Only small blocks for restoration can be obtained; therefore, the outcrops should be protected for such purpose. The area of outcrops and ancient quarries, as well as that of mining activities from the same period, should be preserved as examples of historical extraction techniques and as a remembrance of our geological-materials-based society. Several proposals are presented for the geoconservation of the site.
\end{abstract}

Keywords: natural stone; fracturing pattern; quarrying; geoheritage; Unesco World Heritage Site

\section{Introduction}

The preservation of historic buildings should seek the use of the same original stone material in order to maintain the homogeneity of the aesthetics and the physical-mechanical properties. In addition, using local resources is important for maintaining the cultural heritage, both from the geological and architectural perspectives, by preserving the quarrying and mining landscape and by using the same natural stones that were originally used to build the monuments and historical buildings. Numerous examples highlight building stones as an important part of the tangible heritage of cities, with prominent monuments and historic buildings that can be associated with traditional stones [1-4]. In some cases, the original stone is classified as a heritage stone resource; therefore, the balance between the preservation of the historic building and quarry sites should be promoted. Archeological quarry sites can supply stone pieces for restoration purposes under specific conditions, provided that previous studies have defined quarriable areas which do not affect the historical features of the site.

At present, raw materials are the main subject of many research programs (e.g., Horizon 2020). Within this context, quarrying should also be considered, as it is an activity that should evolve to meet the current standards for security, environment, health and other related issues. Many organisations and groups have the impression that quarrying activities, as well as mining activities, should be banned because they cannot guarantee complete adherence to all these standards, especially as they also undergo modification over time. However, it has been demonstrated that if extractive industries follow strict rules, they can contribute to the advancement of modern society with a minimal negative effect. This assumption is valid no matter the type of resource, metal or stone, the exploitation method, surface or underground, or the size of the affected area [5-9]. 
A conscientious effort has been made to maintain and preserve the historical buildings, though sometimes restoration involving replacement of the stone has not been the best option, largely due to the lack of information concerning the original materials. The International Union of Geological Sciences (IUGS) Subcommission on Heritage Stones (HSS) has been striving to encourage the dissemination of information concerning the original natural stones used in the construction of monuments and historic buildings and also regarding the need for preservation of historical quarries, so that restoration can be done with the original stone [10]. Such is the case of Salamanca, of which a large set of examples of good and bad restoration practices of its buildings has recently been published [4].

The most characteristic stone used in most of the foundations of the historic buildings in the centre of Salamanca is a leucogranite containing clusters of elongated tourmaline crystals, a fabric that inspired the local quarrymen to give it the name of Piedra Pajarilla (little bird stone) [4,10-12]. This granite has been proposed as a candidate for the designation of Global Heritage Stone Resource [10] and together with other stones that crop out in the province and are used in historic buildings of Salamanca, they have been proposed as a candidate for the designation of Global Heritage Stone Province [12]. All these papers make an effort to explain why this resource should be preserved and the quarries maintained, kept not only in reserve for restoration, but also for outreach and education. For these reasons, a detailed characterisation of the ancient quarries and geoconservation measures are needed.

The present paper describes the main characteristic of the Piedra Pajarilla granite and the systematic fracturing affecting the blocks. The intention is to show the local, province and regional governments the advantages of using the same original stone in the restoration of buildings and how the extraction of suitable blocks do not have to importantly alter the ecosystem of the former quarrying sites. It also highlights the potential interest of geoconservation activities, related to economic activities that could enhance the life of a society affected by aging and population exodus.

\section{Materials and Methods}

\subsection{Martinamor Granite}

Piedra Pajarilla is a leucogranite cropping out as thin sub-horizontal sheets (with less than 1 $\mathrm{km}$ width) within the Martinamor Complex, in the Spanish Central System [13]. These granitic sheets formed from the partial melting of a fertile meta-sedimentary protolith, which is part of the Schist-Greywacke complex [14,15], with references therein (Figure 1). Three different facies composed of light-colour minerals can be found-(1) a coarse-grained granite, with nodules of tourmaline, showing a luxullianitic texture; (2) a fine-grained granite with small crystals of tourmaline and (3) a two-mica granite, with the absence of tourmaline. The type most commonly used for construction purposes is the first one [16].

As explained above, luxullianitic textures sometimes resemble flying birds (Figure 2), leading to the local name 'Piedra Pajarilla', used to refer to the construction granite with such texture, and, unfortunately, to many others. 'Piedra Pajarilla' is also known as Martinamor granite, from the village where it was extracted. When different granites are given the same name (due to a lack of knowledge of the different materials by the construction professionals), aesthetic errors can occur, which is considered unacceptable in historic buildings of a World Heritage site [10]. The unique aesthetic characteristics of the 'Piedra Pajarilla' make it difficult to be replaced by other materials. No other material is known, resembling the same aesthetic of this granite. Several other granites originating from other local quarries were used for restoration/replacement of very damaged ashlars, with undesirable aesthetic results [4]. Such confusion can be avoided nowadays by using a certificate of origin (e.g., in Europe, UNE EN 12440 [17]). However, Martinamor granite was used long before the standardisation of stone names came into effect. 


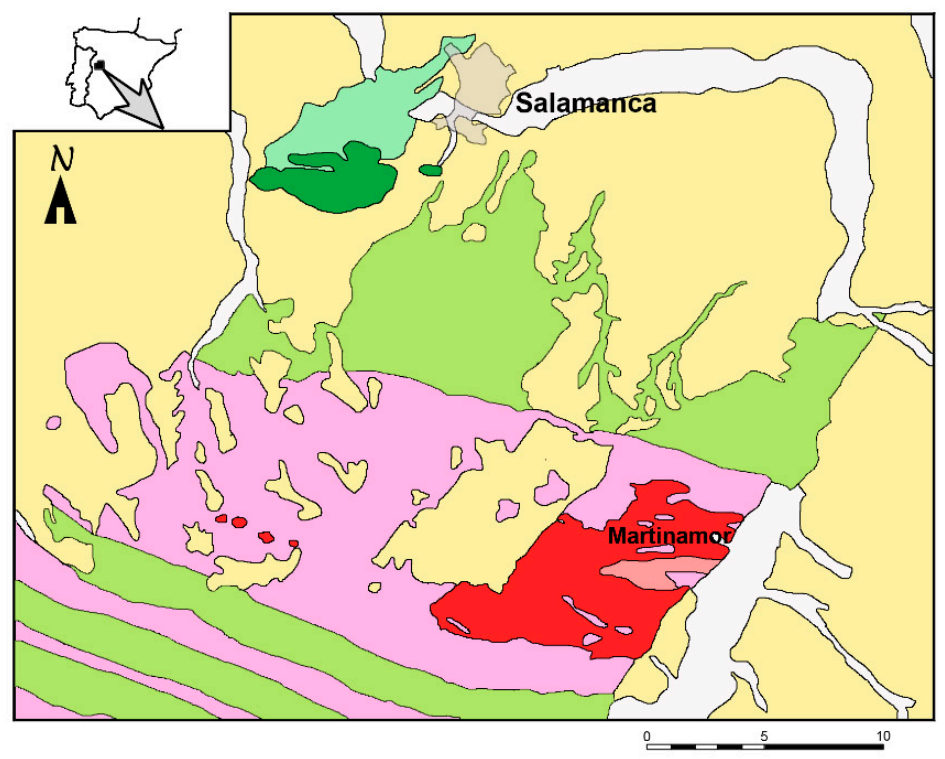

\section{LEGEND}

Quaternary

Quaternary
$\square$ Terraces, alluvial deposits

Tertiary and Quaternary, indeferenciated

$\square$ Sand, clay, sandstone, conglomerate Lower Ordovician

$\square$ Gray slates

Quartzite and basal conglomerate

Schist-Graywacke Complex

$\square$ Aldeatejada Formation - green slates,

sandstones and calcoschists

Monteburrio Formation - slates and schysts

Magmatic rocks

Magmatic rocks
$\square$ Orthogneiss

Granite of Martinamor

Figure 1. Geological setting of Martinamor granite (modified from [13]). The granite cuts the meta-sediments of Cambrian-Precambrian age (the Schist-Greywacke Complex).

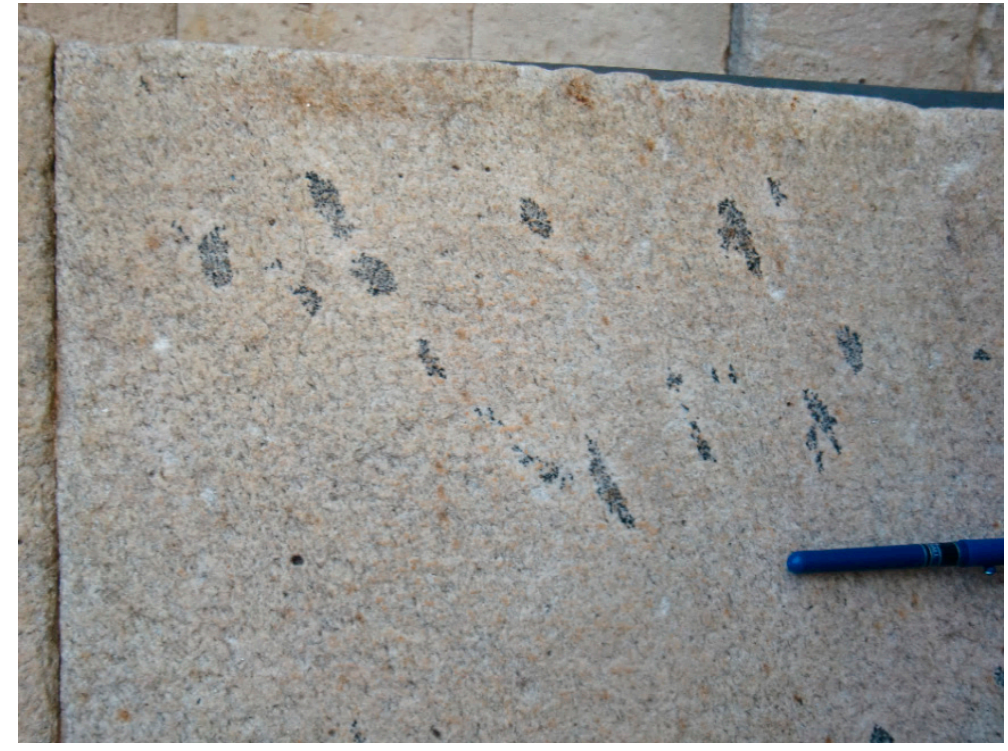

Figure 2. Texture of the granite. The cumulates of tourmaline resemble flying birds.

This granite was stopped being used as a construction material in the early 20th century [10], before quality control was required for the commercial use of stones in construction. Therefore, data regarding its physical or mechanical behaviour are scarce. Previous published characterisations showed high variations in some of the physical and mechanical properties [5,11], but a work that is being carried out at present will show that these characteristics are closely related to the different states of weathering of the rock, the different outcrops that are found in the area and the direction of the testing, regarding the sub-horizontal foliation always present in this granite (Table 1). Weathered granites show high irregularity of the physical-mechanical properties, leading to a very different resistance to water action in ashlars from the same quarry [18]. The historic buildings in Salamanca do not show a high degree of alteration, and this behaviour is a sign that some selection was made by quarrymen at the time, in order to avoid the use of weathering prone granite. 
Table 1. Abbreviated data of the physical and mechanical behaviour of Martinamor granite, depending on the weathering, the sampling area and the direction of the testing (Pereira in prep.).

\begin{tabular}{cccc}
\hline Testing & Compressive Strength & Flexural Strength & Water Absorption \\
\hline Martinamor Granite & $161-252 \mathrm{MPa}$ & $12.7-25.3 \mathrm{MPa}$ & $0.9-0.24 \%$ \\
\hline
\end{tabular}

The restoration of monuments in Salamanca should be performed with appropriate ashlars to ensure good performance. Thus, the full physical-mechanical characterisation of this granite is highly recommended to ensure the utilisation of the material with the desired properties. All the old quarries and usable outcrops should be studied to ensure the best application according to their properties. A full characterisation of this granite will provide a clear picture of the appropriate use of the rock. Authors of this paper are already working on this aspect.

\subsection{Methods}

The first stage was the identification and demarcation of the granite outcrops, quarried or not, through field work and by using aerial photos. In these outcrops, the different spilling marks used in granite exploitation were identified.

In a portion of the outcrops, the strike and dip of fractures were measured with a compass. Rose and pole diagrams drawn with Richard Allmendinger's StereonetWin interface $[19,20]$ allow for fracture assessment. For each fracture set, the spacing was measured perpendicular to the fractures and, afterwards, the histogram was drawn with all the joint spacing data. The mean joint spacing was calculated for the entire data. The volumetric index or volumetric joint count (Jv) [21,22] was calculated based on the mean joint spacing values. This general procedure (strike and joint spacing measurements) was repeated using aerial photos.

Finally, several proposals are presented to accomplish two main purposes. First, create a reserve area for the extraction of granite for the rehabilitation of the monuments in Salamanca. Second, keep the old quarries as an example of extraction techniques and make it possible to show the source of the granite used in many monuments.

\section{Results and Discussion}

\subsection{Quarries and Extraction Techniques}

The quarries are approximately $15 \mathrm{~km}$ south of Salamanca (Figure 3), in the outskirts of Martinamor village (Figure 4), which gives the formal name to the granite. At present, there are two main quarry areas outside Martinamor. The largest one (see Figure 3) is located on private land where cattle are currently kept. Others are located on public land and are composed mainly of intact outcrops (marked as 'Outcrops' in Figure 3). The quarry faces in these two areas are five meters high at their maximum and most of them are only one to two meters high. Other quarry areas are located nearby, but are much smaller in comparison, with no more than $10 \mathrm{~m}$ of historic quarrying, as shown by extraction marks.

So far, all these quarry areas are well preserved, i.e., the quarry fronts are accessible and without topographic modifications. It is possible to observe several quarry faces defined by joints. There are even some vestiges of earlier quarrying methods (Figure 5), which are similar to those observed in ancient Egypt and prehistoric sites in Europe and South America [23,24] (see also http://www.ancient-wisdom.com/quarrymarks.htm). These marks are due to tools used to separate the blocks, both in the vertical and in the horizontal plane. Several types of marks are observed, wedge marks, triangular-shaped drill holes and circular drill holes. Wedge marks are the oldest. Several researches mention the Roman period as the origin of this marks [25-29]. However, only a detailed archaeological investigation will permit accurate conclusions about the wedge marks observed in the area. 


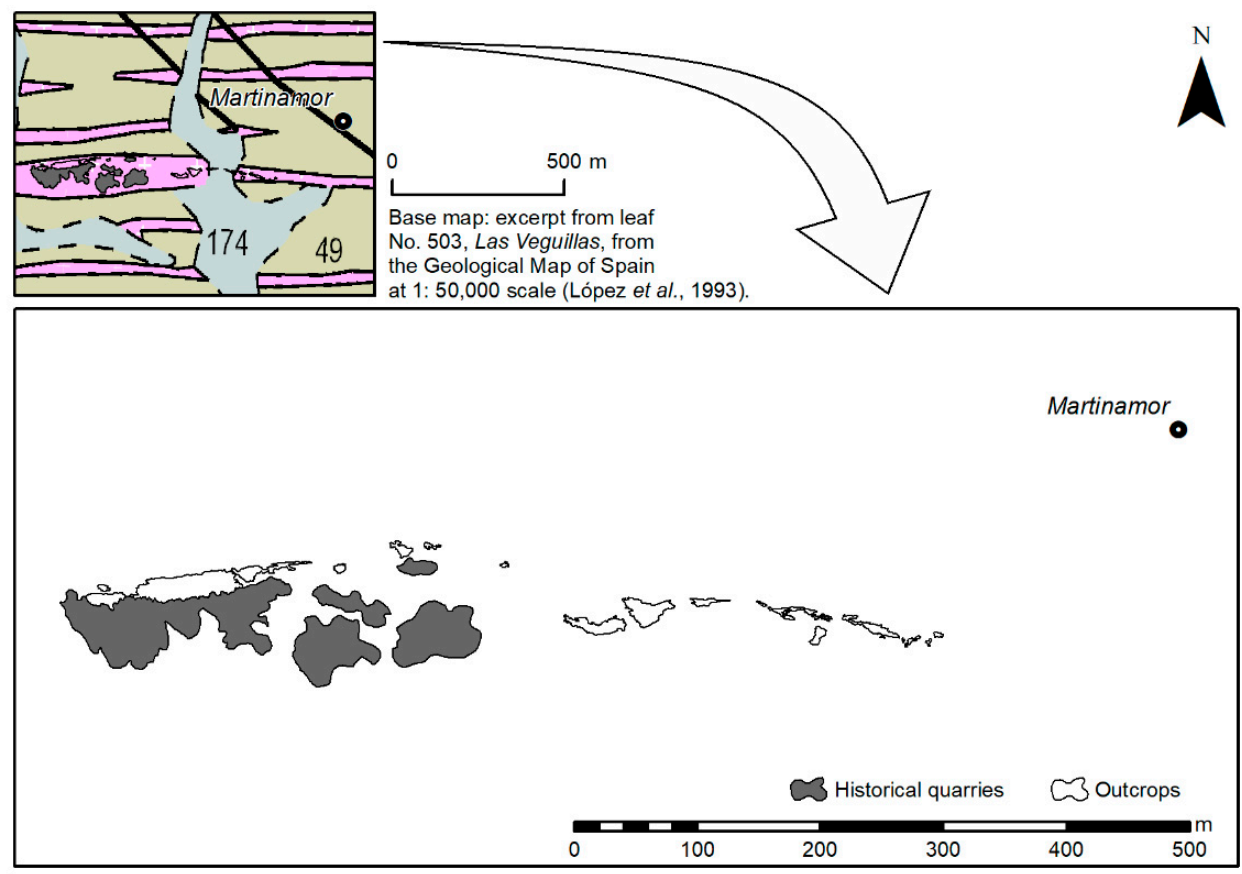

Figure 3. Location of the historical quarries near Martinamor (according to [13], 49, slates and limolites, Monterrubio Formation; 174, aluvial deposits; pink bodies, two-mica granites, leucogranites with tourmaline and sincinematics with Hercynian Phase II).

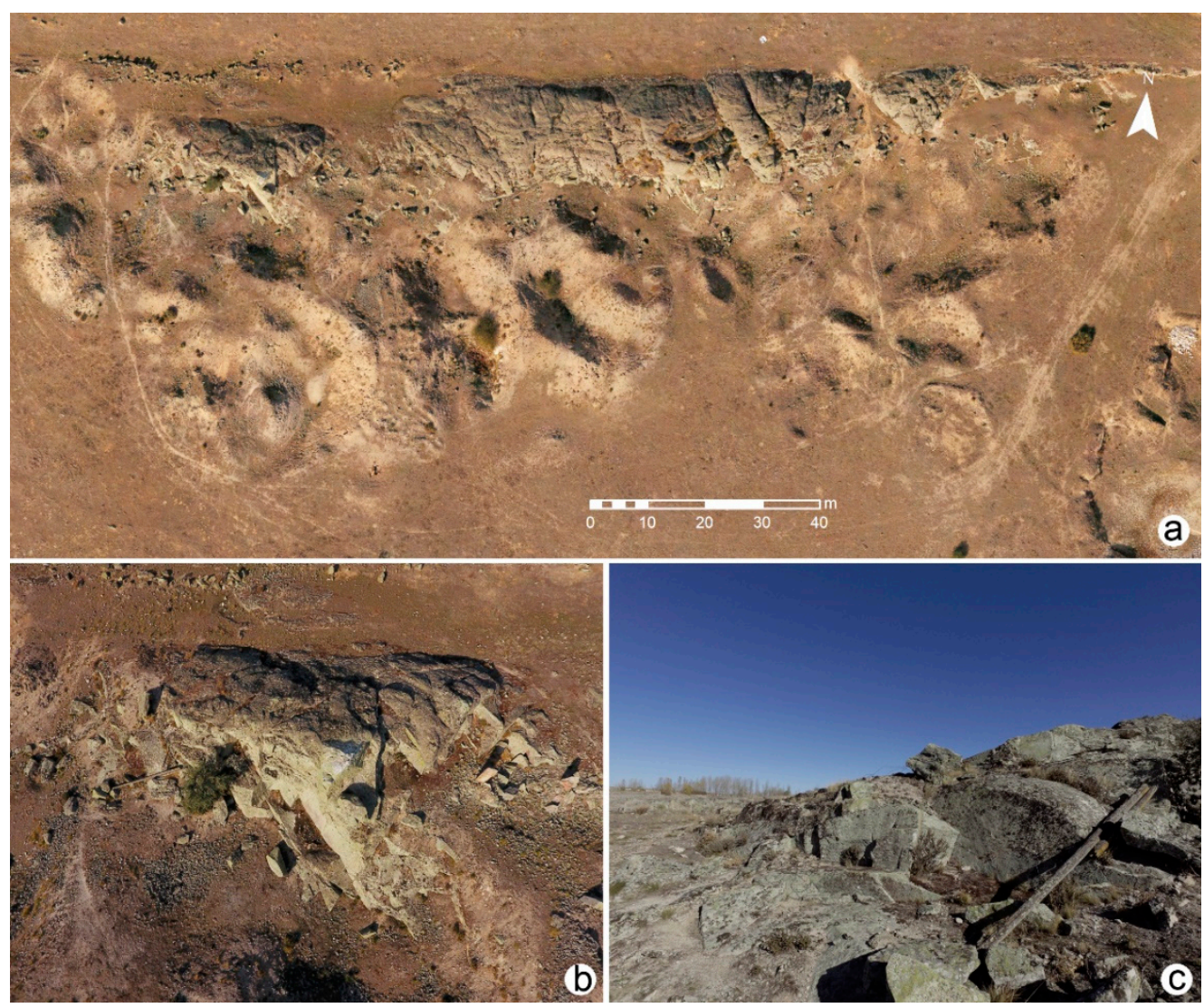

Figure 4. Photos of the ancient quarries. (a) aerial photomosaic of the largest quarry where it is possible to see a large amount of affected land due to the historic extractions; $(\mathbf{b}, \mathbf{c})$ details of the quarry front. 


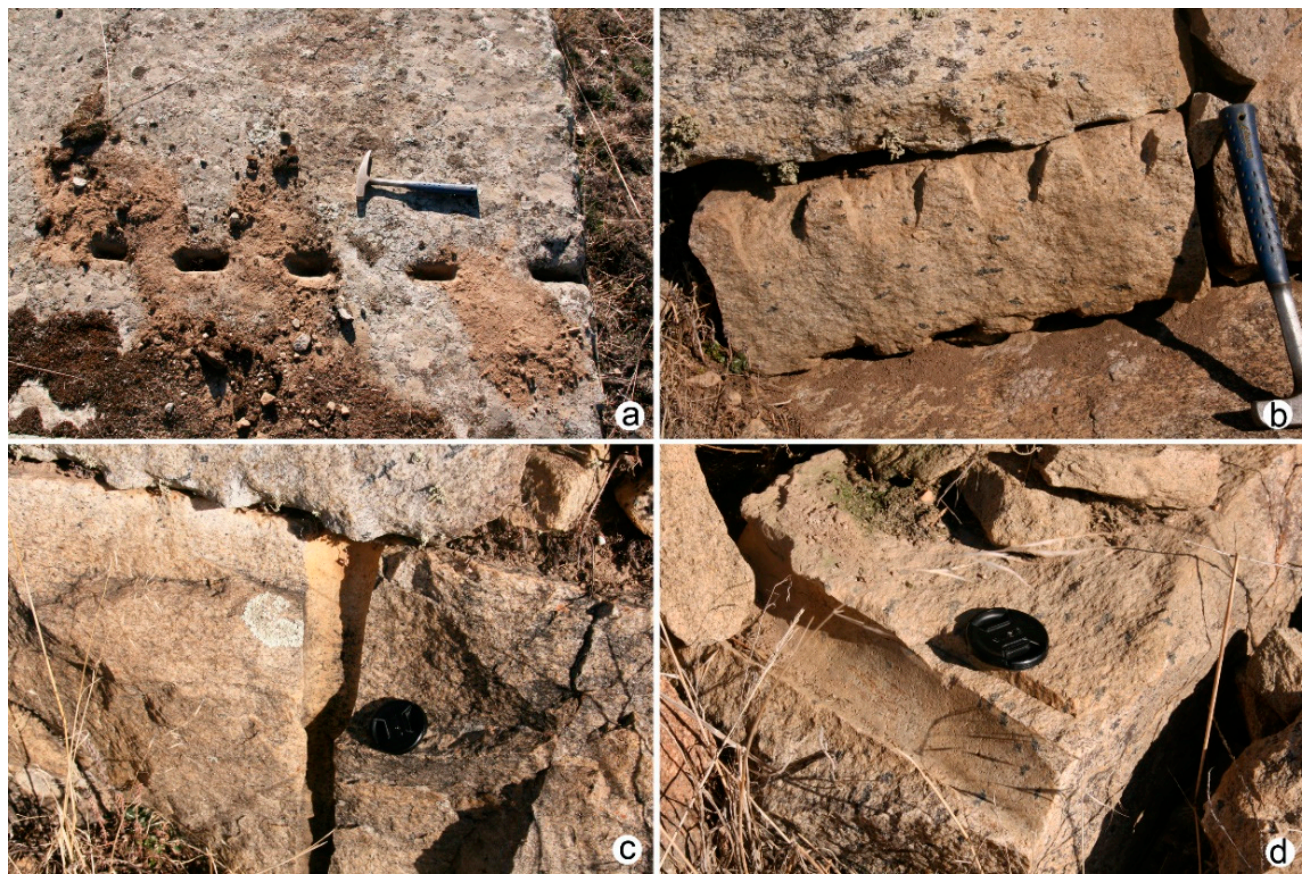

Figure 5. Splitting marks in ancient quarries of Martinamor granite: $(\mathbf{a}, \mathbf{b})$ wedge (rectangular) marks and (c,d) triangular-shaped drill holes.

The triangular-shaped drill holes are barely seen in quarries and not common in the literature. Hockensmith [30] mentions triangular holes with a maximum depth of $18 \mathrm{~cm}$ in a limestone quarry, probably produced by a pick. Gage [31] studied several triangular drill holes with a maximum depth of $1.5 \mathrm{~m}$ depth in a graphite mine. According to this author "there is a strong possibility that the points of the triangular shape holes were used to direct the line of fracture during the blast". Some of the triangular holes observed in the old quarries near Martinamor show one corner aligned with natural fractures, pointing out the practical purpose of such holes.

This topic is worth investigating further [32] in order to identify all the splitting marks in the quarried area, as well as to highlight the evolution of the drill techniques through time. This is an extra reason to work on a preservation figure for this area.

\subsection{Fracturing and Resources Evaluation}

The pattern and density of fracturing define the possibility of extracting granite blocks for further extraction and applications. The study of fractures has proven to be a useful method to discern whether a sufficient quantity of dimension stones can be extracted from a quarry [33] and whether the fracturing can be used in the extraction process, facilitating the quarrying and therefore lowering the cost. Our purpose is to investigate whether it would be feasible to use some of the blocks for restoration of monuments and historical buildings in Salamanca because it has been observed that in some cases other types of granite have been incorrectly used to replace deteriorated ashlars. This has led to undesirable aesthetic effects that should not be permitted in a historical site, especially for a World Heritage Site.

In a first stage, fracturing was evaluated in the outcrops near the Martinamor village (see Figure 3). The most important joint sets are $\mathrm{N} 20^{\circ}-40^{\circ} \mathrm{W}$, dipping to $\mathrm{NE}$, and $\mathrm{N} 50^{\circ}-60^{\circ} \mathrm{E}$, dipping to $\mathrm{NW}$. However, the span between these main directions is continuous (Figure 6). When the two main joint sets were present, the quarrymen took advantage of them (they are perpendicular) to facilitate the extraction of granite blocks. In this area, the joint spacing values are low (Figure 7), with most of them below one meter. The overall mean joint spacing of 78 values is $0.64 \mathrm{~m}$, with slight differences between the $\mathrm{N} 20^{\circ}-40^{\circ} \mathrm{W}$ and $\mathrm{N} 50^{\circ}-60^{\circ} \mathrm{E}$ sets, with the mean values of $0.57 \mathrm{~m}(\mathrm{n}=40)$ and $0.69 \mathrm{~m}(\mathrm{n}=20)$, 
respectively. Neglecting the influence of the horizontal joints, the volumetric joint count (Jv) is 3.2. This value is far above the threshold usually considered for the financial revenue in quarries for ornamental purposes, $\mathrm{Jv}=2.0$ [21]; however, the joint spacing values are enough to obtain small blocks able to produce ashlars.
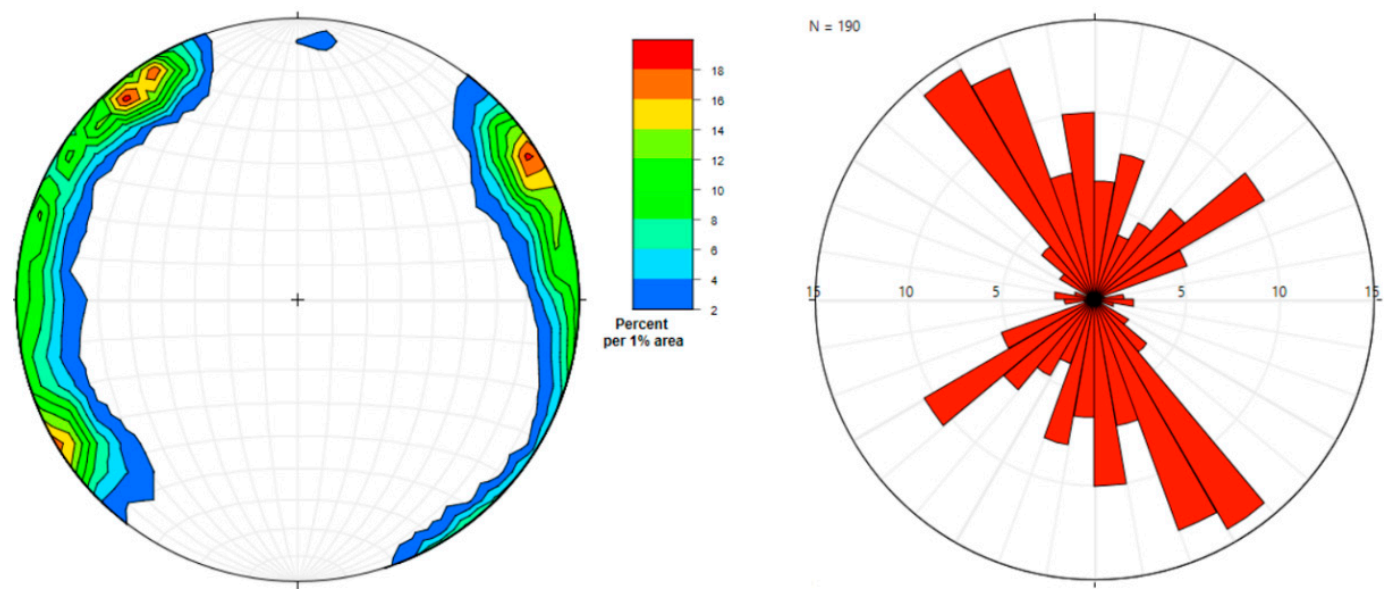

Figure 6. Distribution of the joints measured in the field work ( $\mathrm{n}=190$; low hemisphere).

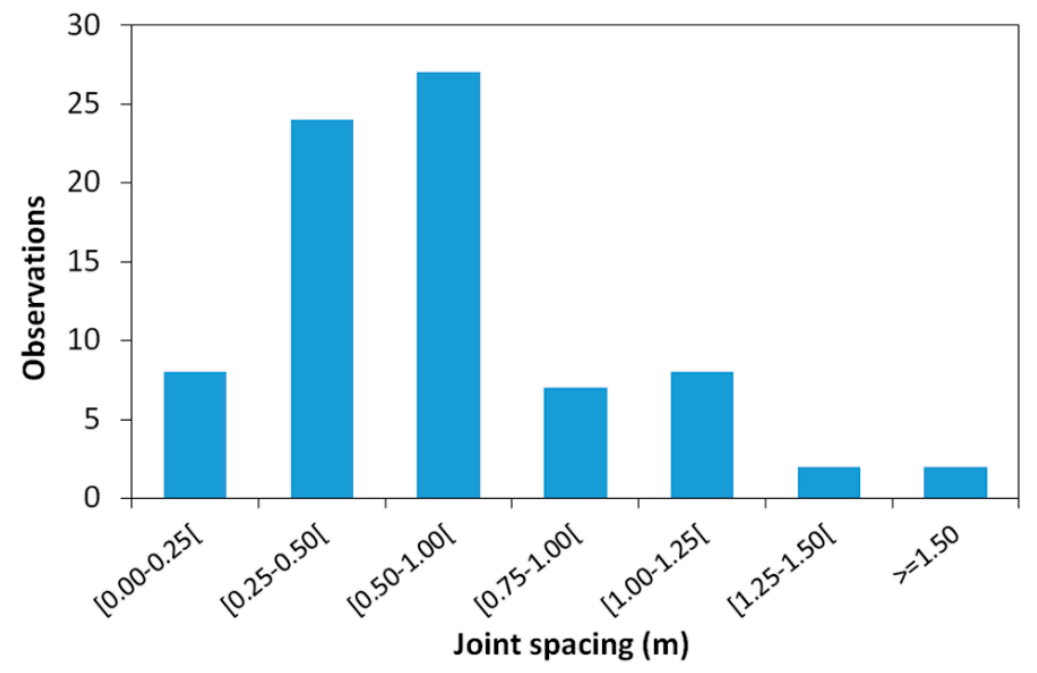

Figure 7. Distribution of the joint spacing data from field measurements.

Analysis of the fracture pattern can be easily carried out using photomosaics obtained by an unmanned aerial vehicle for aerial photographs. This technique was used to study the fracturing in the remaining outcrops (see Figure 3). An example of fracturing identification in outcrops is presented in Figures 8 and 9 , regarding an outcrop located southwest of Martinamor. The $\mathrm{N} 40^{\circ}-50^{\circ} \mathrm{W}$ set fractures stand out, while the $\mathrm{N} 70^{\circ}-80^{\circ} \mathrm{W}, \mathrm{N} 30^{\circ}-50^{\circ} \mathrm{E}$ and $\mathrm{N} 70^{\circ}-80^{\circ} \mathrm{E}$ sets are also important. The mean joint spacing $(\mathrm{n}=104)$ is $0.87 \mathrm{~m}$ and volumetric joint count $(\mathrm{Jv})$ is equal to 3.4 . The same methodology was applied in the outcrops located near the ancient quarries (see Figure 3) and the results can be seen in Figure 10. In this area, the joints have a more random distribution with the predominance of the $\mathrm{N} 50^{\circ}-60^{\circ} \mathrm{W}, \mathrm{N} 20^{\circ}-30^{\circ} \mathrm{W}, \mathrm{N} 60^{\circ}-70^{\circ} \mathrm{E}$ and $\mathrm{N} 80^{\circ}-90^{\circ} \mathrm{W}$ sets. The overall mean joint spacing $(\mathrm{n}=198)$ is equal to $1.3 \mathrm{~m}$ and the volumetric joint count (Jv) is 3.9 . 


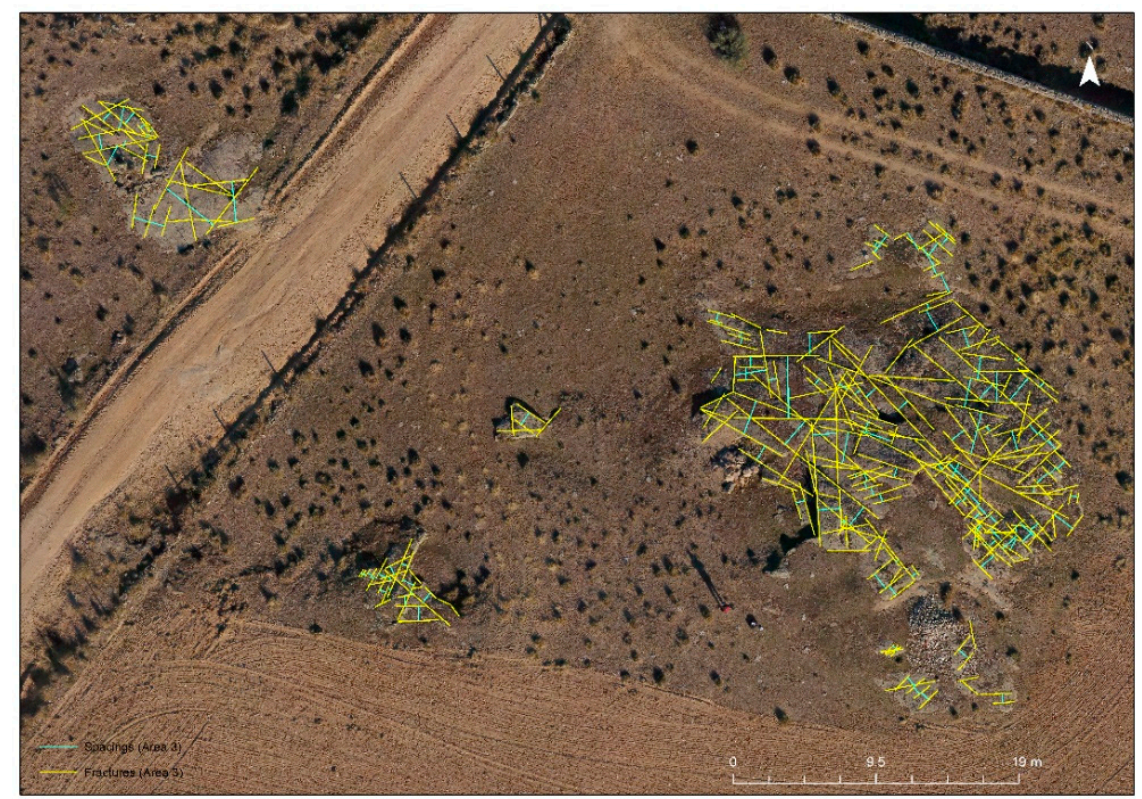

Figure 8. Example of fracturing identification in aerial photomosaic (yellow lines, joints; green lines, joint spacing).
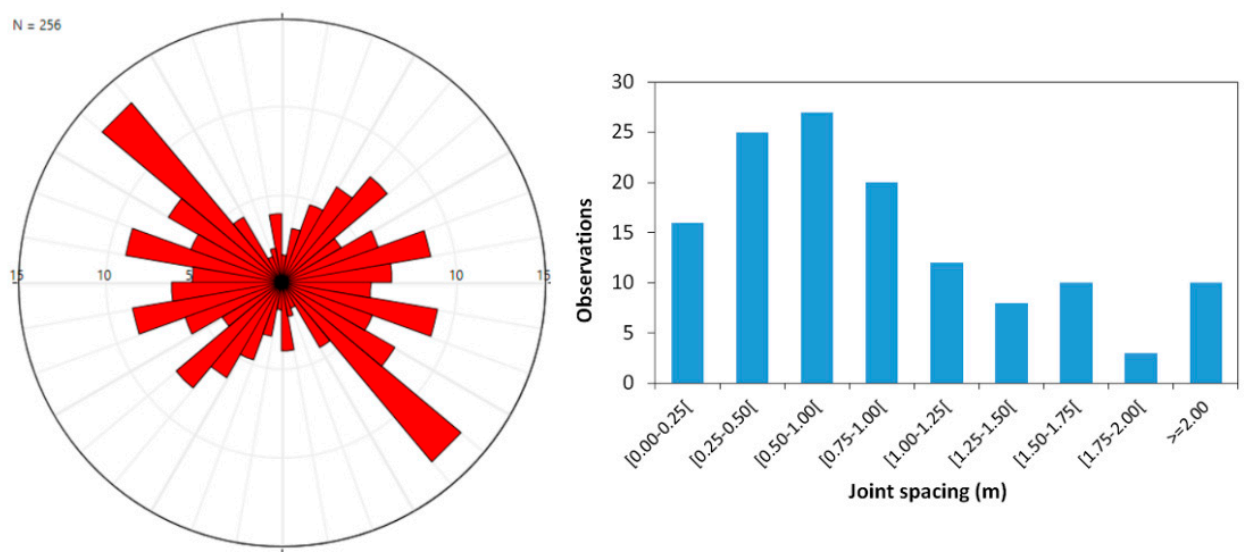

Figure 9. Fractures and joint spacing data from outcrops identified in Figure 8.
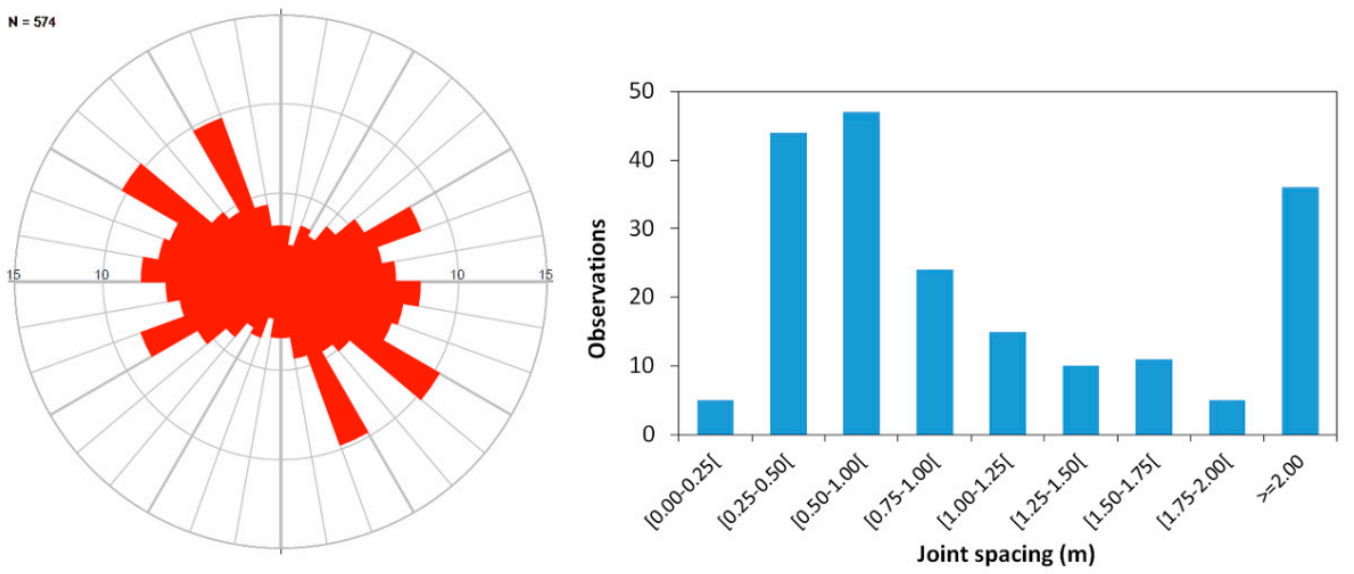

Figure 10. Rose diagram and joint space distribution relative to outcrops located near the ancient quarries (see Figure 3).

The fracturing pattern is slightly different within the studied areas, with the main joint set located in the $\mathrm{N} 20^{\circ}-60^{\circ} \mathrm{W}$ range, as well as other important joint sets. Consequently, fracturing patterns define 
natural blocks with a shape far away from the ideal cube or rectangular cuboid. The overall mean joint spacing ranges from $0.64 \mathrm{~m}$ to $1.3 \mathrm{~m}$ and volumetric joint count values are higher than 3.2 (3.2-3.9).

The results confirm the high fracturing density and the impossibility of extracting large blocks. Therefore, considering the available outcrops, a massive exploitation of this granite is unlikely. However, the possibility of extracting small blocks for restoration support the idea of protecting this area as a reserve for such purpose.

\subsection{The Need for a Geoconservation Proposal}

Our proposal considers different assets of the granite and its outcrops, the practical application of granite as source of restoration material, the scientific and educational potentiality of the quarries, the heritage values and recreational opportunities. The monuments located in Salamanca act as the trigger for further actions (Figure 11). In view of the historical importance of such monuments, all the restorations must be done taking into consideration the properties of the original stone. For that reason, the quarries should be studied and protected. In the scheme of Figure 11, the geoconservation measures at quarries are the consequence of monument heritage concern.

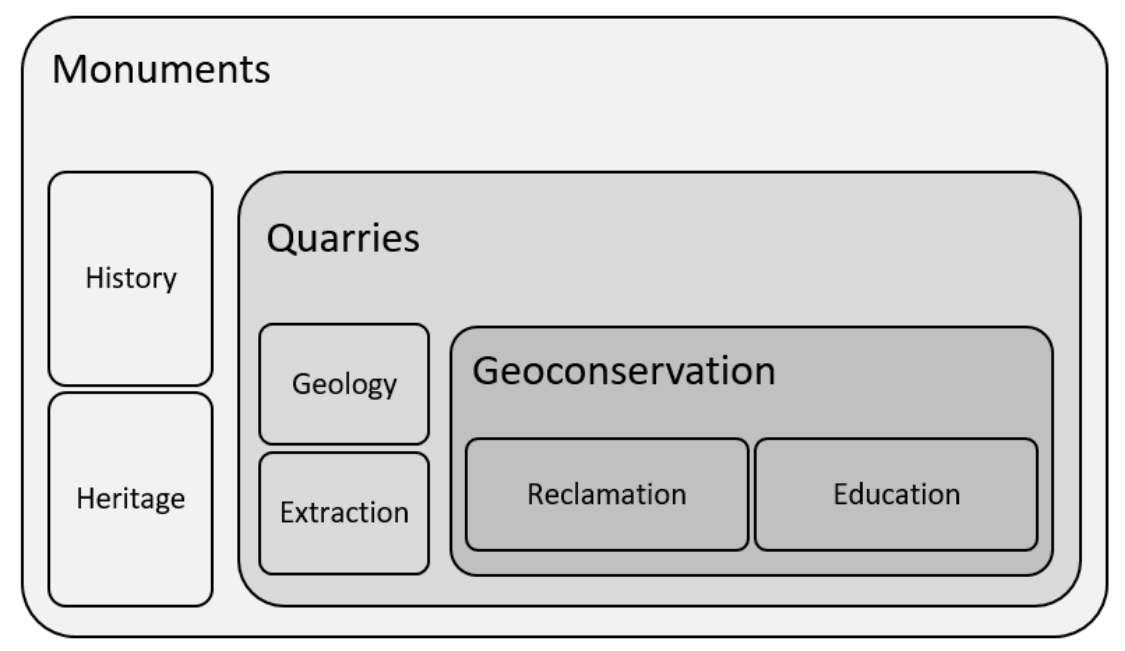

Figure 11. Geoconservation as an instrument for the conservation of monuments.

In order to avoid using stones that do not match the original ones, only designated materials, i.e., the same materials or materials with properties similar to those in the original fabrics should be used to avoid physical or aesthetic damage [34]. Therefore, regarding the outcrops of Martinamor granite, only the ones able to supply granite pieces for restoration purposes, need to be classified as a special reserve. Knowledge of the physical-mechanical properties of the granite is a key factor to avoid chaotic restorations that diminish the historical value of the monuments. Textural properties, e.g., texture, grain size and colour, should be considered when other stones are used. Such properties must resemble the original stone as much as possible. For this reason, initiatives such as the heritage stones designations by IUGS are important to provide the description and characterisation of stones that are not always commercialised or even extracted these days.

The location of the source of the material used in heritage monuments is important as a testimony of the progress in building techniques. It is also possible to make the connection between the monuments and the surrounding area, since the source of the stone is usually located not far away $[35,36]$. Old quarries allow us to understand the alteration process of the material, to establish their durability and provide valuable information in view of the restoration and conservation works. The Geomonumental Routes [37] are excellent examples of a holistic approach of how to promote the heritage interlocking history and science. The location of the village of Martinamor (a village dramatically affected by aging and population exodus) near the outcrops will permit the use of a rehabilitated house as a welcome centre, where visitors can have a first insight into the quarrying 
activities before the guided field trip. There are many examples of similar approaches in areas transformed by the mining activity that make it possible to outline the best options [38-40].

Other geological resources exploited in the neighbourhood can be added to this route, such as the tungsten mines and orthogneiss quarries. Salamanca province experienced active mining of tungsten, tin and cupper during and after the Second World War. The price of tungsten was very high, even higher than gold, because the Germans needed it for tungsten carbide tools and for armour-piercing munitions, among other things. The Allies tried to stop them from buying the tungsten, which was extracted from various mines in Spain and Portugal, so the price increased dramatically. There is a considerable amount of historical information regarding the efforts on both sides and even some fiction derived from the subject [41,42]. Tungsten mining in this area was closed in the 1970s because the price dropped. However, the landscape is full of abandoned mines which are part of the cultural heritage. The orthogneisses of San Pelayo, located nearby, are considered a Point of Geological Interest (POGI) [43]. The stone shows a typical compositional banded appearance defined by quartzfeldpsar and mica layers, biotite enriched and with lenticular eye-shaped feldspars. This orthogneiss is closely related to the enrichment of tungsten, and tailings with quite a lot of scheelite are witnesses of the mining that took place there as a main economic activity of the area.

In the case of Martinamor granite, the few small available outcrops are highly fractured for a regular exploitation; therefore, their present appearance will not be changed by quarrying activity. However, agroforest activities and cattle herding can affect the outcrops and their impact needs to be assessed. Protecting the outcrops is the priority and the municipality should create the legal bases for it. Another important issue is the attractiveness of the quarry landscape. Several factors can make the experience of a field trip more pleasant, such as a natural succession, quarry preservation, the presence of surface water, human activity, accessibility, among others [44]. Therefore, some improvements are necessary to enrich the area and increase its attractiveness. In some parts of the area, ecological restoration and rehabilitation actions are required to recover the degraded ecosystem. However, in the remaining portions of the outcrops/quarries, reclamation actions should not hide the quarry fronts, preventing access to the material and to features of scientific and educational interest, such as fracturing and evidence of the extraction techniques used in the past. This case can be an interesting example of post-mining land use as discussed by Kaźmierczak et al. [45] and Cross et al. [46].

In the above approach (Figure 11), monuments act as the starting point for a sequence of actions where geoconservation is the ultimate end. Another option, without changing the main actions to be undertaken, is the holistic point of view where monuments and the quarries are part of something wider and universal (Figure 12). In this case, monuments are an excellent example of the interaction between human beings and their geological environs, as with many other human actions such as the settlement location or territory dispute. The available stones influence construction techniques and the monumentality of the buildings; therefore, the quarry location is an important issue related to monument restoration. Monuments are examples of the interaction between human beings and their geological environs, particularly in terms of the available stones. Both options (Figures 11 and 12) have the same activities in the quarries/outcrops, since reclamation/ecological restoration/rehabilitation are required for environmental protection, as well as consensual extraction for restoration purposes. The only difference between the two approaches is the starting point, which can be the monument heritage (Figure 11) or the geological heritage (Figure 12).

The details of the geoconservation proposal will be presented in a subsequent publication, namely the reclamation and rehabilitation actions in a quarried area, with the delimitation of the outcrops available for granite extraction. Our aims are to design the overall arrangements in the outcrops area in order to make it easier to access and turn the field trip into an agreeable activity. Also, the visiting schema should be planned according to several options, such as the following: a guided or free visit; location of the starting point; educational level and age of the visitors. Our goal is to contribute to the preservation of the monumental heritage of Salamanca, aiming to promote awareness of the importance of the geological resources and to expand the initiative to other similar cases in 
Europe and around the world. In the study area, as well as in many other places around the world, there is a need of further studies dedicated to understand ancient tools and ancient quarrying activities in order to facilitate the preservation of monuments and historic buildings for the mutual benefit of the local community, the environment, and science in general [47].

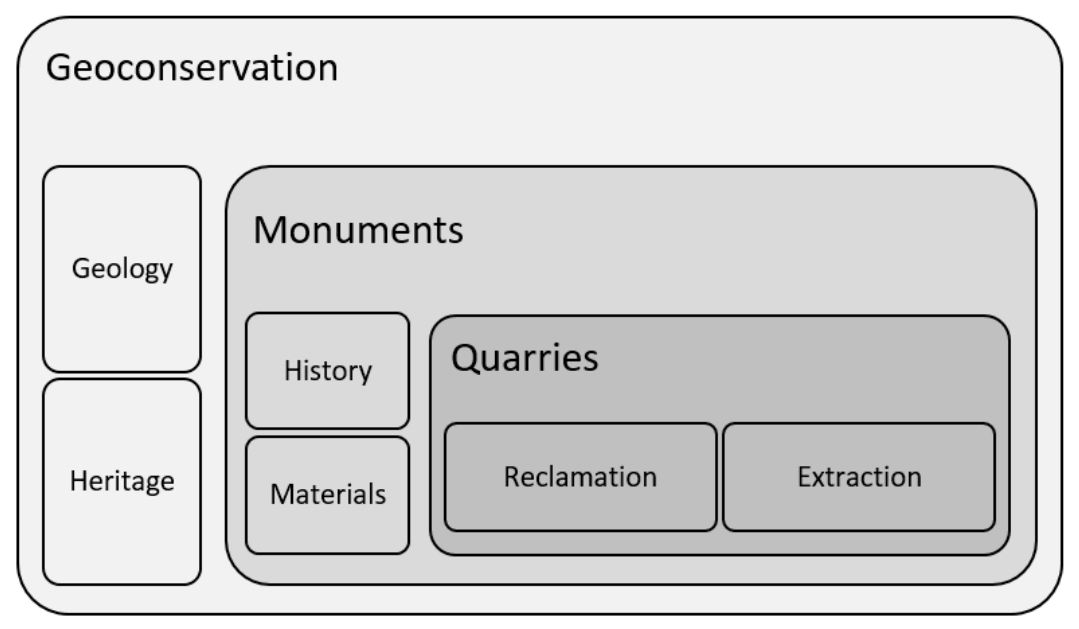

Figure 12. Holistic approach to the geoconservation actions.

\section{Conclusions}

Scientific research can show how past mining and quarrying activities have been carried out, but also how they can be part of much needed new endeavours. Traditional geological methods, such as mapping and petrology, contribute to the understanding and preservation of historical natural stone quarries that were used to build the architectural heritage of so many societies. Furthermore, the different extraction techniques and their evolution are recognisable in quarry faces.

A dense fracturing pattern cutting Martinamor granite doesn't allow the extraction of large blocks necessary for the modern stone industry. However, the extraction of small pieces for restoration, meeting the physical-mechanical and textural standards, is possible. This study will facilitate the potential re-use of an abandoned quarry, where stone to build a World Heritage city was quarried centuries ago, adapting to the very strict mining and environment laws regarding re-opening mines and quarries. An overall reclamation scheme is suitable for the quarried area in order to improve both its accessibility for educational/scientific visits and for extraction when restoration is necessary.

It is important to recognise that education and outreach programmes are very important activities to maintain the knowledge of past mining and quarrying traditions, as part of our cultural heritage, as well as to remind people that these are positive activities which are vital for the advance of modern societies. Therefore, a geoconservation safeguarding plan should be undertaken to ensure the protection and designation of this important quarry area.

This research is the first step for a sustainable use of the small outcrops of Martinamor granite. Considering the area available for potential quarrying and the fracturing density, only ashlars for restoration purposes can be extracted. The limited amount of granite resources highlights the inevitability of strict rules to access: what monuments can use these quarries for the potential restoration/conservation? What outcrops can be used? In fact, quarries are themselves an archaeological site. Therefore, a wider plan is necessary to manage the exploitation/rehabilitation of the area. Geoconservation proposals are tentative to put the quarries in a wider study perspective, make easier their protection and restricted utilisation. This means a comprehensive sustainability, including cultural heritage, scientific principles and environmental concerns. 
Author Contributions: All authors contributed equally to this paper.

Funding: This research was part of a program funded by the following institutions: Fundación Universidad-Empresa, the Castilla y Leon regional government and the University of Salamanca. It is also part of the activities of the UNESCO IGCP-637. The FCT -Fundação para a Ciência e a Tecnologia, I.P., project UID/Multi/00073/2019 of the Geosciences Center, also supported this research.

Acknowledgments: The use of Stereonet software is acknowledged.

Conflicts of Interest: The authors declare no conflict of interest.

\section{References}

1. Luodes, N.; Panova, E.; Bellopede, R. Characterization of natural stone material used in the Nordic eastern urban and costal environment. Environ. Earth Sci. 2017, 76, 328. [CrossRef]

2. Freire-Lista, D.M.; Fort, R. Historical City Centres and Traditional Building Stones as Heritage: Barrio de las Letras, Madrid (Spain). Geoheritage 2019, 11, 71-85. [CrossRef]

3. Menningen, J.; Siegesmund, S.; Lopes, L.; Martins, R.; Sousa, L. The Estremoz marbles: An updated summary on the geological, mineralogical and rock physical characteristics. Environ. Earth Sci. 2018, 77, 191. [CrossRef]

4. Pereira, D. Natural stone and World Heritage: Salamanca (Spain); CRC Press: Bota Raton, FL, USA, 2019.

5. Yang, Y.-Y.; Xu, Y.-S.; Shen, S.-L.; Yuan, Y.; Yin, Z.-Y. Mining-induced geo-hazards with environmental protection measures in Yunnan, China: An overview. Bull. Eng. Geol. Environ. 2015, 74, 141-150. [CrossRef]

6. Essalhi, A.; Essalhi, M.; Toummite, A. Environmental impact of mining exploitation: A case study of some mines of barite in the Eastern Anti-Atlas of Morocco. J. Environ. Prot. 2016, 7, 1473-1482. [CrossRef]

7. Ozcelik, M. Environmental pollution and its effect on water sources from marble quarries in western Turkey. Environ. Earth. Sci. 2016, 75, 796. [CrossRef]

8. OECD. Managing environmental and health impacts of uranium mining; NEA: Paris, France, 2014.

9. Mensah, A.K.; Mahiri, I.O.; Owusu, O.; Mireku, O.D.; Wireko, I.; Kissi, E.A. Environmental impacts of mining: A study of mining communities in Ghana. Appl. Ecol. Env. Res. 2015, 3, 81-94.

10. Pereira, D.; Gimeno, A.; del Barrio, S. Piedra Pajarilla: A candidacy as a Global Heritage Stone Resource for Martinamor granite. Geol. Soc. London, Spéc. Publ. 2014, 407, 93-100. [CrossRef]

11. Cooper, B.; Marker, B.; Pereira, D.; Schouenborg, B. Establishment of the "Heritage Stone Task Group" (HSTG). Episodes 2013, 36, 8-10.

12. Pereira, D.; Cooper, B.J. Building stone as a part of a World Heritage Site: 'Piedra Pajarilla' Granite and the city of Salamanca, Spain. Geol. Soc. London, Spéc. Publ. 2013, 391, 7-16. [CrossRef]

13. Díez Balda, M.A. El Complejo Esquisto-Grauvaquico, las series Paleozoicas y la estructura Hercínica al Sur de Salamanca; Ediciones Universidad de Salamanca: Salamasca, Spain, 1986; 162p.

14. Díez Balda, M.A.; Vegas, R.; González Lodeiro, F. Central Iberian Zone. In Pre-Mesozoic Geology of Iberia; Dallmeyer, R.D., Martinez-Garcia, E., Eds.; Springer: Berlín, Germany, 1990; pp. 172-188.

15. Pereira, M.D.; Rodríguez-Alonso, M.D. Duality of cordierite granites related to melt-restite segregation in the Peña Negra Anatectic Complex, central Spain. Can. Mineral. 2000, 38, 1329-1346.

16. López Plaza, M.; Sánchez, M.G.; Iñigo, A.C. La utilización del leucogranito turmalinífero de Martinamor en los monumentos de Salamanca y Alba de Tormes. Stud. Geol. Salmant. 2007, 43, 247-280.

17. UNE EN 12440 Natural Stone: Denomination Criteria; The National Standards Authority of Ireland: Dublin, Ireland, 2008.

18. Sousa, L.; Siegesmund, S.; Wedekind, W. Salt weathering in granitoids: An overview on the controlling factors. J. Environ. Earth Sci. 2018, 77, 502. [CrossRef]

19. Cardozo, N.; Allmendinger, R.W. Spherical projections with OSXStereonet. Comput. Geosci. 2013, 51, $193-205$. [CrossRef]

20. Richard Allmendinger's Home Page. Available online: https://personalpages.manchester.ac.uk/staff/Richard. Allmendinger/ (accessed on 22 May 2019).

21. Sousa, L.M.O.; Oliveira, A.S.; Alves, I.M.C. Influence of fracture system on the exploitation of building stones: The case of the Mondim de Basto granite (north Portugal). Environ. Earth Sci. 2016, 75, 39. [CrossRef]

22. Palmström, A. The volumetric joint count-a useful and simple measure of the degree of jointing. In Proceedings of the 4th international congress of IAEG, New Delhi, India, 10-15 December 1982; pp. 182, 221-228. 
23. Heldal, T. Constructing a quarry landscape from empirical data. General perspectives and a case study at the Aswan west bank, Egypt. In QuarryScapes: Ancient stone quarry landscapes in the Eastern Mediterranean; Abu-Jaber, N., Bloxam, E.G., Degryse, P., Heldal, T., Eds.; Geological Survey of Norway Special Publication: Trondheim, Norway, 2009; Volume 12, pp. 125-153.

24. Wootton, W.; Russell, B.; Rockwell, P. Stoneworking tools and toolmarks (version 1.0). The Art of Making in Antiquity: Stoneworking in the Roman World. 2013. Available online: http://www.artofmaking. ac.uk/content/essays/2-stoneworking-tools-and-toolmarks-w-wootton-b-russell-p-rockwell/ (accessed on 5 February 019).

25. Hori, Y. Ancient Quarry Techniques in the Ptolemaic Period in the Middle Egypt. In Proceedings of the XVII International Congress of Classical Archaeology, Roma, Italy, 22-26 September 2008.

26. Harrell, J.A.; Storemyr, P. Ancient Egyptian quarries-an illustrated overview. In QuarryScapes: Ancient stone quarry landscapes in the Eastern Mediterranean; Abu-Jaber, N., Bloxam, E.G., Degryse, P., Heldal, T., Eds.; Geological Survey of Norway Special Publication: Trondheim, Norway, 2009; Volume 12, pp. 7-50.

27. Coli, M.; Rosati, G.; Pini, G.; Baldi, M. The Roman quarries at Antinoopolis (Egypt): Development and techniques. J. Archaeol. Sci. 2011, 38, 2696-2707. [CrossRef]

28. Verhoeven, G.; Taelman, D.; Vermeulen, F. Computer vision-based orthophoto mapping of complex archaeological sites: The ancient quarry of Pitaranha (Portugal-Spain). Archaeometry 2012, 54, 1114-1129. [CrossRef]

29. Carfora, P.; Di Luzio, E. Archaeomorphological and Geological Studies on the Ancient Appian Way at the Aurunci Pass: Multidisciplinary Approaches for the Investigation of Ancient Quarries Siting and Exploitation. In Proceedings of the 3rd International Landscape Archaeology Conference, Rome, Italy, 17-20 September 2014.

30. Hockensmith, C.D. Archaeological Investigations at the Shrull Lime Kiln Near Russellville, Logan County, Kentucky. In Current Archaeological Research in Kentucky; Mills, E.N., Williamson, R.V., Davis, R.D., Eds.; Kentucky heritage council: Frankfort, KY, USA, 2007; Volume 9, pp. 1-26.

31. Gage, J. Osgood Graphite Mine, Nelson NH Site Report. 2002. Available online: http://www.stonestructures. org/html/graphite_mine.html (accessed on 6 February 2019).

32. Gage, M.; Gage, J. The art of splitting stone. Early Rock Quarrying Methods in Pre-Industrial New England; Powwow River Books: Amesbury, MA, USA, 2005.

33. Sousa, L.M.O. Granite fracture index to check suitability of granite outcrops for quarrying. Eng. Geol. 2007, 92, 146-159. [CrossRef]

34. Pereira, D.; Marker, B. The Value of Original Natural Stone in the Context of Architectural Heritage. Geosciences 2016, 6, 13. [CrossRef]

35. Freire-Lista, D.M.; Fort, R.; Varas-Muriel, M.-J. Alpedrete granite (Spain). A nomination for the “Global Heritage Stone Resource" designation. Episodes 2015, 38, 106-133.

36. Freire-Lista, D.M.; Fort, R.; Varas-Muriel, M.-J. San Pedro leucogranite from A Coruña, Northwest of Spain: Uses of a heritage stone. Energy Procedia 2016, 97, 554-561. [CrossRef]

37. Traditional building stone in Madrid monuments. Available online: https://www.madrimasd.org/English/ Science-Society/scientific-heritage/Geomonumental-Routes/madrid/default.asp (accessed on 8 May 2019).

38. Careddu, N.; Siotto, G.; Siotto, R.; Tilocca, C. From landfill to water, land and life: The creation of the Centre for stone materials aimed at secondary processing. Resour. Policy 2013, 38, 258-265. [CrossRef]

39. Carrión Mero, P.; Herrera Franco, G.; Briones, J.; Caldevilla, P.; Domínguez-Cuesta, M.; Berrezueta, E. Geotourism and Local Development Based on Geological and Mining Sites Utilization, Zaruma-Portovelo, Ecuador. Geoscience 2018, 8, 205. [CrossRef]

40. Prosser, C.D. Geoconservation, Quarrying and Mining: Opportunities and Challenges Illustrated Through Working in Partnership with the Mineral Extraction Industry in England. Geoheritage 2018, 10, 259-270. [CrossRef]

41. Guerra Garrido, R. El año del wólfram, 1st ed.; Catedra Ediciones: Madrid, Spain, 1984; 354p.

42. Wilson, R. A small death in Lisbon; Harper Collings Publishers: London, UK, 1999; 440p.

43. IGME Point of Geological Interest. Available online: http://info.igme.es/ielig/LIGInfo.aspx?codigo=CIs027 (accessed on 8 May 2019).

44. Baczyńska, E.; Lorenc, M.W.; Kaźmierczak, U. The Landscape Attractiveness of Abandoned Quarries. Geoheritage 2018, 10, 271. [CrossRef] 
45. Kaźmierczak, U.; Lorenc, M.W.; Strzałkowski, P. The analysis of the existing terminology related to a post-mining land use: A proposal for new classification. Environ. Earth Sci. 2017, 76, 693. [CrossRef]

46. Cross, A.T.; Young, R.; Nevill, P.; McDonald, T.; Prach, K.; Aronson, J.; Wardell-Johnson, G.W.; Dixon, K.W. Appropriate aspirations for effective post-mining restoration and rehabilitation: A response to Kaźmierczak et al. Environ. Earth Sci. 2018, 77, 256. [CrossRef]

47. Goette, H.R.; Pajor, F. Eduard Schaubert's travel notes on Southern Euboea in May 1847. Mediterr. Archaeol. Archaeom. 2010, 3, 63-64.

(C) 2019 by the authors. Licensee MDPI, Basel, Switzerland. This article is an open access article distributed under the terms and conditions of the Creative Commons Attribution (CC BY) license (http://creativecommons.org/licenses/by/4.0/). 